\title{
Unilateral short root anomaly: an incidental finding on routine radiographic examination
}

\author{
Ratna Rachel Ponraj, ${ }^{1}$ Renu Sarah Samson, ${ }^{1}$ Vijayendranath Sujir Nayak, ${ }^{1}$ \\ Melwin Mathew ${ }^{2}$
}

${ }^{1}$ Orthodontics, Melaka Manipal Medical College, Bukit Baru, Melaka, Malaysia

${ }^{2}$ Periodontics, Melaka Manipal Medical College, Bukit Baru, Melaka, Malaysia

\section{Correspondence to}

Dr Ratna Rachel Ponraj; drratnarachelponraj@gmail.com

Accepted 14 December 2020

\section{DESCRIPTION}

A 19-year old female patient with the report of irregularly placed upper front teeth sought orthodontic treatment. Clinically, she exhibited an edge to edge incisal relationship and class III malocclusion. Panoramic radiograph revealed the presence of all teeth including four unerupted third molars. Teeth 16, 26 and 36 were restored due to dental caries. The periodontal and supporting tissues were found to be healthy. Due to suspicion of dental caries on teeth 11 and 12, an intraoral periapical radiograph (IOPA) was taken, which showed abnormally short and conical root with respect to tooth 11 , along with well-defined radiopacity on the distoproximal aspect of tooth 11 suggestive of previous restoration. Thereafter, a detailed radiological examination was carried out using cone beam CT (CBCT) in order evaluate the short-rooted tooth, ${ }^{12}$ sectional image obtained from the CBCT showed that total length of the tooth was $14.57 \mathrm{~mm}$, crown length from incisal tip to cementoenamel junction (CEJ) was $10.18 \mathrm{~mm}$ and root length from CEJ to the tip of the root was $4.40 \mathrm{~mm}$, (figure 1A-C). The labial alveolar bone concavity over tooth 11 appeared to be more pronounced as compared with the bone morphology of the adjacent tooth 21 (figure 1D,E). This finding suggests a possible developmental aetiology.

On further evaluation, the patient stated no history of trauma or previous orthodontic
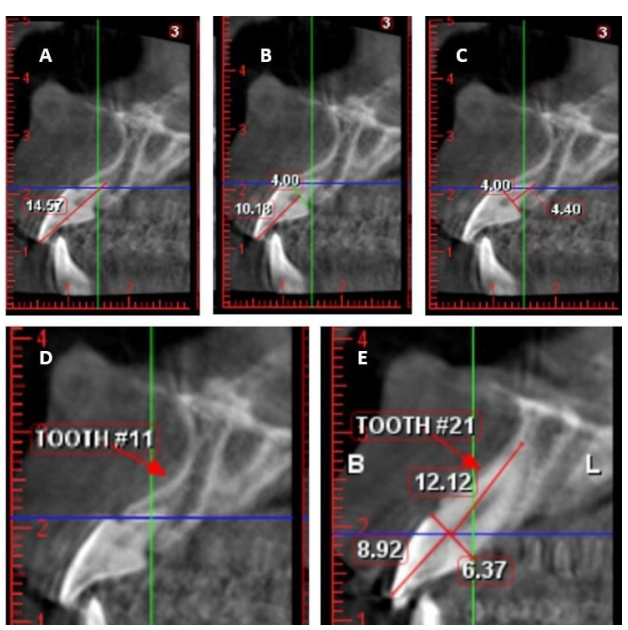

Figure 1 Cone beam CT image of $(A)$ total length of tooth 11, (B) crown length of tooth 11, (C) root length of tooth 11, (D) labial alveolar bone morphology of tooth 11 and (E) labial alveolar bone morphology of tooth 21 with measurements.

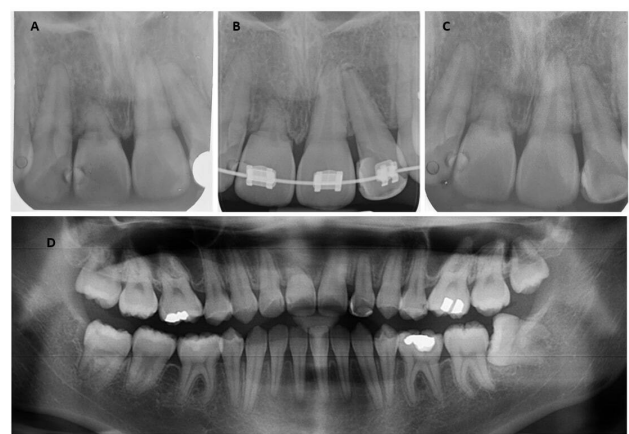

Figure 2 (A) Pretreatment IOPA, (B) during treatment IOPA, (C) posttreatment IOPA of tooth 11 and (D) posttreatment panoramic radiograph showing unaltered root and bone structure after orthodontic treatment. IOPA, intraoral periapical radiograph.

treatment. Clinically, the crown of tooth 11 had the same size and morphology when compared with the unaffected tooth 21. This is in accordance with the literature on short root anomaly cases. ${ }^{3}$ The root is theoretically considered short when its crown-root ratio is more than $1: 1{ }^{4}$ Tooth 11 did not exhibit any signs of mobility and tested positive for pulp sensibility. All these findings were suggestive of short root anomaly (SRA).

SRA is a rare condition that is often allied with genetic predisposition and higher female predilection. ${ }^{5-9}$ The aetiology of SRA is mostly characterised as idiopathic. ${ }^{10}$ Other suggested aetiologies include congenital or developmental origin, ${ }^{37}$ external influences like trauma, ${ }^{11}$ syndromes, ${ }^{12-14}$ chemotherapy and radiotherapy ${ }^{15}$ Literature affirms that this condition always affects both the central incisors. ${ }^{4}$ On the contrary, the clinical report presented here displays a case of unilateral pattern of SRA. Additionally, the root length was considerably short in comparison to its bilateral counterpart. Based on the literature search, there is a dearth in reports exhibiting unilateral cases of SRA, which makes this report unique.

\section{Patient's perspective}

I was unaware of this condition as I had never experienced any pain or distinct tooth movement involving my incisor. I am relieved to know that the tooth is stable and orthodontic therapy has improved the longevity of the tooth. 


\section{Learning points}

- Pretreatment orthodontic radiographs are extremely helpfu in careful evaluation of the crown-root ratio of individual teeth in order to rule out iatrogenic root resorption.

- Pretreatment radiographs can also be used as baseline or reference points to evaluate further reduction in root length due to resorption arising from inadvertent forces. Hence, periodic radiographs must be taken to monitor the root resorption of the teeth.

- Judicious weighing of risks and benefits is recommended before commencing orthodontic treatment because each case of SRA will pose unique challenges to the clinician. In case of mobility of the affected tooth/teeth, orthodontic treatment might not be indicated. Asymptomatic teeth however can be moved orthodontically keeping tooth movement to a minimum.

- Using light forces throughout the treatment by having longer intervals between activations and appointments will ensure better stability in the long term.

Orthodontic treatment was initiated since the tooth 11 was asymptomatic. However, light intermittent forces were employed to bring about tooth movement and to prevent deleterious effects on tooth $11 .^{16-18}$ Prior to treatment onset, the patient was informed about the condition she presented with and the limitations, risks and objectives of treatment. After signing an informed consent form, orthodontic therapy was initiated. During the course of treatment, constant monitoring of root and bone tissue in relation to the tooth 11 with SRA was ensured. ${ }^{19} 20$ Orthodontic treatment was satisfactorily completed with sufficient overjet, overbite, incisor angulation and stable posterior occlusion. The posttreatment IOPA and panoramic radiograph revealed unaltered root morphology with adequate bone support, implying that orthodontic treatment is not an absolute contraindication in asymptomatic SRA ${ }^{5} 5^{21-23}$ (figure 2). The patient will be followed up over the next 5 years on a 6 -month interval to monitor the prognosis of the tooth.

Acknowledgements The authors would like to thank Prof Dr Abdul Rashid Haji Ismail, for the relentless support and encouragement in the publication of this case report as well as the Department of Oral Radiology for the expert services offered.

Contributors RRP contributed to the documentation, manuscript writing and correspondence. RSS was involved in manuscript writing, editing and submission. VSN contributed to imaging and investigations. MM contributed in manuscript editing and submission.

Funding The authors have not declared a specific grant for this research from any funding agency in the public, commercial or not-for-profit sectors.

Competing interests None declared.
Patient consent for publication Obtained.

Provenance and peer review Not commissioned; externally peer reviewed.

\section{REFERENCES}

1 Mah JK, Huang JC, Choo H. Practical applications of cone-beam computed tomography in orthodontics. J Am Dent Assoc 2010;141 Suppl 3:7S-13.

2 Dudic A, Giannopoulou C, Leuzinger M, et al. Detection of apical root resorption after orthodontic treatment by using panoramic radiography and cone-beam computed tomography of super-high resolution. Am J Orthod Dentofacial Orthop 2009;135:434-7.

3 Luder HU. Malformations of the tooth root in humans. Front Physio/ 2015;6:307.

4 Lind V. Short root anomaly. Scand J Dent Res 1972;80:85-93.

5 Apajalahti S, Arte S, Pirinen S. Short root anomaly in families and its association with other dental anomalies. Eur J Oral Sci 1999;107:97-101.

6 Lamani E, Feinberg KB, Kau CH. Short Root Anomaly - A Potential "Landmine" for Orthodontic and Orthognathic Surgery Treatment of Patients. Ann Maxillofac Surg 2017;7:296-9.

7 Apajalahti S, Hölttä P, Turtola L, et al. Prevalence of short-root anomaly in healthy young adults. Acta Odonto/ Scand 2002;60:56-9.

8 Venkataraghavan K, Karthik S, Krishnakumar K. Short Root Anomaly-A Rare Occurrence: Review Of Literature \& Report Of A Case. Indian Journal of Dental Sciences 2014;6.

9 Yu M, Jiang Z, Wang Y. Molecular mechanisms for short root anomaly. Oral Dis 2020;00:1-9.

10 Desai RS, Vanaki SS, Puranik RS, et al. An unusual combination of idiopathic generalized short-root anomaly associated with microdontia, taurodontia, multiple dens invaginatus, obliterated pulp chambers and infected cyst: a case report. J Oral Pathol Med 2006;35:407-9.

11 Tewari N, Pandey RK. Root hypoplasia: an unusual sequela to primary tooth trauma. Dent Traumatol 2010;26:115-7.

12 Prahl-Andersen B, Oerlemans J. Characteristics of permanent teeth in persons with trisomy G. J Dent Res 1976;55:633-8.

13 Roinioti TD, Stefanopoulos PK. Short root anomaly associated with RothmundThomson syndrome. Oral Surg Oral Med Oral Pathol Oral Radiol Endod 2007;103:e19-22.

14 Bansal S, Bansal P, Gupta A. Generalized severe short root anomaly: a diagnostic dilemma. Indian Journal of Oral Sciences 2015;6:88.

15 Näsman M, Björk 0, Söderhäll S, et al. Disturbances in the oral cavity in pediatric long-term survivors after different forms of antineoplastic therapy. Pediatr Dent 1994;16:217.

16 Valladares Neto J, Rino Neto J, de Paiva JB. Orthodontic movement of teeth with short root anomaly: should it be avoided, faced or ignored? Dental Press J Orthod 2013;18:72-85.

17 Rey D, Smit RM, Gamboa L. Orthodontic treatment in patient with idiopathic root resorption: a case report. Dental Press J Orthod 2015;20:108-17.

18 Vishwanath M, Chen P-J, Upadhyay M, et al. Orthodontic management of a patient with short root anomaly and impacted teeth. Am J Orthod Dentofacial Orthop 2019;155:421-31.

19 Marques LS, Generoso R, Armond MC, et al. Short-root anomaly in an orthodontic patient. Am J Orthod Dentofacial Orthop 2010;138:346-8.

20 Tanaka OM, Knop LHA, Shintcovsk RL, et al. Treatment of a patient with severely shortened maxillary central incisor roots. J Clin Orthod 2008;42:729-31.

21 Farret MM, Farret MMB. Retreatment of a class II patient with short-root anomaly. J Clin Orthod 2015;49:659-65.

22 Edwards DM, Roberts GJ. Short root anomaly. Br Dent J 1990;169:292-3.

23 Cutrera A, Allareddy V, Azami N, et al. Is short root anomaly (SRA) a risk factor for increased external apical root resorption in orthodontic patients? A retrospective case control study using cone beam computerized tomography. Orthod Craniofac Res 2019;22:1-6. 
Copyright 2021 BMJ Publishing Group. All rights reserved. For permission to reuse any of this content visit https://www.bmj.com/company/products-services/rights-and-licensing/permissions/

BMJ Case Report Fellows may re-use this article for personal use and teaching without any further permission.

Become a Fellow of BMJ Case Reports today and you can:

- Submit as many cases as you like

- Enjoy fast sympathetic peer review and rapid publication of accepted articles

Access all the published articles

Re-use any of the published material for personal use and teaching without further permission

Customer Service

If you have any further queries about your subscription, please contact our customer services team on +44 (0) 2071111105 or via email at support@bmj.com.

Visit casereports.bmj.com for more articles like this and to become a Fellow 